\title{
PERANAN MOTIVASI DAN KOMPETENSI: ANALISIS KINERJA PEGAWAI PEMERINTAHAN DAERAH KABUPATEN PASER
}

\section{Dedy Darmawan}

STIE Widya Praja Tanah Grogot

Jl. Jend. Sudirman Tana Paser Kalimantan Timur

E-mail: dedy310@gmail.com

\begin{abstract}
This study aims to determine the effect of motivation variables (X1) and competence (X2) on employee performance (Y) simultaneously and partially in the Public Relations and Protocol Section of the Paser Regency Regional Secretariat. The analysis method uses multiple linear regression. The population in this study were all employees in the Public Relations and Protocol Section at the Paser Regency Regional Secretariat. The sample of this study was 32 people. Simultaneous testing shows that there is at least one independent variable $(X)$, which affects the dependent variable. Furthermore, partial testing is carried out, which shows the effect of motivation (XI) has a significant effect on employee performance $(Y)$ of 5.440. While the competency variable (X2) does not affect employee performance $(Y)$. The adjusted $R$ square is 0.472 ; which means that the variation of motivation (X1) and competence (X2) can explain the performance (Y) of 47.2\% while the rest is explained by other unknown factors of 52.8\%. Based on the results of the analysis, motivation (XI) is a very dominant variable affecting the performance of employees in the Public Relations and Protocol Section at the Paser Regency Regional Secretariat. This causes competence not to have a significant effect on employee performance.
\end{abstract}

Keywords: motivation, competency and employee performance.

\begin{abstract}
Abstrak
Penelitian ini bertujuan untuk mengetahui pengaruh variabel motivasi (X1) dan kompetensi (X2) terhadap kinerja pegawai (Y) secara simultan dan parsial pada Bagian Humas dan Protokol di Sekretariat Daerah Kabupaten Paser. Metode analisis menggunakan regresi linear berganda. Populasi dalam penelitian ini adalah seluruh pegawai pada Bagian Humas dan Protokol di Sekretariat Daerah Kabupaten Paser. Sampel penelitian ini sebanyak 32 Orang. Pengujian secara simultan menunjukkan bahwa minimal terdapat satu variabel bebas (X) yang berpengaruh terhadap variabel terikat. Selanjutnya, dilakukan pengujian secara parsial yang menunjukkan pengaruh motivasi (X1) berpengaruh signifikan terhadap kinerja pegawai (Y) adalah sebesar 5,440. Sedangkan variabel kompetensi (X2) tidak berpengaruh terhadap kinerja pegawai (Y). Nilai koefisien determinasi (adjusted R square) sebesar 0,472; artinya variasi motivasi (X1) dan kompetensi (X2) dapat menjelaskan kinerja (Y) sebesar $47,2 \%$ sedangkan sisanya dijelaskan oleh faktor lain yang tidak diketahui sebesar $52,8 \%$. Berdasarkan hasil analisis, motivasi (X1) merupakan variabel yang sangat dominan mempengaruhi kinerja pegawai pada Bagian Humas dan Protokol di Sekretariat Daerah Kabupaten Paser. Hal ini menyebabkan kompetensi tidak berpengaruh signifikan terhadap kinerja pegawai.
\end{abstract}

Kata kunci : motivasi, kompetensi dan kinerja pegawai. 


\section{PENDAHULUAN}

Sejalan dengan perkembangan dunia kerja yang semakin global, pengelolaan suatu organisasi harus dilakukan secara professional serta produktif, sehingga organisasi tetap dapat mempertahankan hidupnya dan terus berkembang seiring dengan kemajuan zaman. Konsep pengembangan umumnya dilakukan terhadap Pegawai yang berfungsi sebagai roda penggerak organisasi. Pengembangan pegawai harus dilakukan dengan kontinuitas yang terpelihara baik serta terarah. Satu hal yang perlu diperhatikan adalah pegawai sebagai sumber daya manusia yang handal tidak muncul begitu saja, namun memerlukan suatu proses pengembangan yang bertahap dan berkesinambungan.

Untuk mencapai kinerja pegawai yang maksimal, penggunaan motivasi yang tepat dari atasan, merupakan salah satu faktor yang dapat menggerakkan, mengarahkan, membimbing dan memotivasi pegawai untuk lebih berprestasi dalam bekerja. Pemimpin dapat mempengaruhi moral, kepuasan kerja, keamanan, kualitas kehidupan kerja dan terutama tingkat prestasi suatu organisasi. Kemampuan dan keterampilan motivasi dalam pengarahan adalah faktor penting efektivitas pemimpin (Lamsah, 2018; Nisa, Serudji, Sulastri, 2019). Bila organisasi dapat mengidentifikasikan kualitas-kualitas yang berhubungan dengan motivasi, kemampuan untuk menyeleksi pemimpin-pemimpin yang efektif akan meningkat, bila organisasi dapat mengidentifikasikan perilaku dan teknikteknik motivasi efektif organisasi, berbagai perilaku dan teknik tersebut akan dapat dipelajari.

Kompetensi merupakan seperangkat pengetahuan, keterampilan perilaku yang harus dimiliki seseorang dalam melaksanakan tugas keprofesionalannya (Pramudyo, 2010). Sedangkan menurut Rivai dan Sagala (2009), kompetensi merupakan keinginan untuk memberikan dampak pada orang lain dan kemampuan untuk mempengaruhi orang lain melalui strategi membujuk dan mempengaruhi. Menurut Grote dalam Pramudyo (2010), kompetensi dapat digunakan untuk memprediksi kinerja, yaitu siapa yang berkinerja baik dan kurang baik tergantung pada kompetensi yang dimilikinya, diukur dari kriteria atau standar yang digunakan.

Faktor motivasi yang akan mempengaruhi kinerja pegawai yang dimiliki seseorang adalah merupakan potensi, dimana seseorang belum tentu bersedia untuk mengerahkan segenap potensi yang dimilikinya untuk mencapai hasil yang optimal, sehingga masih diperlukan adanya pendorong agar seorang pegawai mau menggunakan seluruh potensinya (Abdussamad, 2017). Daya dorong tersebut sering disebut motivasi. Melihat kenyataan tersebut, sudah saatnya pimpinan dapat lebih banyak memberikan kesempatan kepada pegawai mengembangkan sumber daya manusia agar lebih berprestasi dalam melaksanakan tugas pelayanan terhadap masyarakat (Maulida, 2018). Bagian Humas dan Protokol melaksanakan kegiatan yang secara bertahap mengacu kepada Rencana Program Kerja yang telah ditetapkan. Keberhasilan dan pengukuran kegiatan-kegiatan di bagian Humas dan Protokol dapat dilihat dari pencapaian kinerja kegiatan dari tahun-tahun sebelumnya. Dari program dan kegiatan yang telah dilaksanakan tersebut diatas, Bagian Humas dan Protokol senantiasa berupaya mengetahui setiap proses pembangunan, baik pada tahap perencanaan, pengorganisasian pelaksanaan dan tahap evaluasi (Suherman dan safitri, 2018). Untuk itu secara terus-menerus ditingkatkan optimalisasi SDM yang ada, sehingga tercipta lingkungan kerja yang kondusif, demokratis, sehat dan dinamis. Kondisi ini sangat berpengaruh dan berdampak langsung terhadap proses keberhasilan pelaksanaan tugas dan fungsi Humas dan Protokol.

Namun demikian dari program dan kegiatan yang telah dilaksanakan Ada beberapa faktor yang menjadi kendala dan hambatan didalam melaksanakan tugas dan fungsinya antara lain : 1. kurangnya koordinasi dengan Instansi terkait; 2. kurangnya diklat SDM Bagian Humas dan Protokol; 3. kurang optimalnya dukungan anggaran dalam pelaksanaan kegiatan; 4. kurangnya pemahaman Aparatur Humas dan 
Protokol terhadap tugas dan fungsinya dan; 5. kurangnya intensitas serta kedisiplinan aparatur Humas dan Protokol dalam mengemban visi dan misinya. Hal ini merupakan tantangan sekaligus peluang untuk meningkatkan kinerja Bagian Humas dan Protokol.

Oleh karena itu, perlu dirumuskan secara mendalam, kerja-kerja secara terpadu dan berkesinambungan melalui penerapan Pengaruh Motivasi dan Kompetensi Terhadap Kinerja Pegawai Pada Bagian Humas dan Protokol di Sekretariat Daerah Kabupaten Paser.

Berdasarkan latar belakang tersebut, rumusan masalah dalam penelitian ini adalah: (1) Bagaimana pengaruh motivasi pegawai terhadap kinerja pegawai Bagian Humas dan Protokol di Sekretariat Daerah Kabupaten Paser?; (2) Bagaimana pengaruh kompetensi terhadap kinerja pegawai Bagian Humas dan Protokol di Sekretariat Daerah Kabupaten Paser?; (3) Bagaimana pengaruh motivasi dan kompetensi secara bersama-sama terhadap kinerja pegawai Bagian Humas dan Protokol di Sekretariat Daerah Kabupaten Paser?

\section{TINJAUAN PUSTAKA}

Menurut Hasibuan (2003) motivasi merupakan dorongan karyawan atau sikap mental karyawan yang mengarah atau mendorong perilaku kearah pencapaiaan kebutuhan yang memberikan kepuasan. Berdasarkan definisi tersebut maka dapat disimpulkan bahwa motivasi kerja adalah keadaan dalam pribadi seseorang yang mendorong keinginan individu untuk melakukan pekerjaan tertentu guna mencapai tujuan.

Two Factors Theory Herzberg dan Teori Motivasi Berprestasi McClelland (Achievement Motivation Theory), digunakan sebagai grand theory untuk menjelaskan konsep teori secara umum tentang motivasi kerja yang dikaitkan dengan kebutuhan seseorang dalam mencapai prestasi. Achievement Motivation Theory dikemukakan oleh McClelland dalam Robbins, S dan Judge, T.A. (2008:225)

McClelland yang menjelaskan tiga motif atau kebutuhan utama yang relevan di tempat kerja, yaitu ;

1. Need for Achievement (nAch), kebutuhan untuk berprestasi, yang merupakan refleksi dari dorongan akan tanggung jawab untuk pemecahan masalah. Kebutuhan untuk berprestasi adalah kebutuhan untuk melakukan pekerjaan lebih baik dari pada sebelumnya, selalu berkeinginan mencapai prestasi yang lebih tinggi.

2. Need for Affiliation (nAff), kebutuhan untuk berhubungan sosial, yang merupakan dorongan untuk berinteraksi dengan orang lain atau berada bersama orang lain, tidak mau melakukan sesuatu yang merugikan orang lain.

3. Need for Power (nPow), kebutuhan untuk berkuasa, yang merupakan refleksi dari dorongan untuk mencapai otoritas/ kekuasaan, serta untuk memiliki pengaruh terhadap orang lain.

Kompetensi merupakan seperangkat pengetahuan, keterampilan perilaku yang harus dimiliki seseorang dalam melaksanakan tugas keprofesionalannya (Pramudyo, 2010). Teori Model Gunung Es (Iceberg Model), digunakan sebagai grand theory untuk menjelaskan konsep teori secara umum tentang kompetensi kerja. Teori ini dikemukakan oleh Spencer \& Spencer dalam Wijayanto, et al (2011:82) :

"Kompetensi didefinisikan sebagai kemampuan manusia yang ditemukan saat praktek, serta dapat digunakan untuk membedakan antara mereka yang sukses superior dengan yang biasa-biasa saja di tempat kerja. Kompetensi berada pada tingkatan niat intent dan tindakan yang dapat memberikan hasil di tempat kerja. Segala niat dan tindakan yang tidak memberikan hasil 
baik, tidak dapat dikategorikan sebagai kompetensi."

Kompetensi dapat dikategorikan ke dalam dua bentuk yaitu; hard competency dan soft competency. Hard competency merupakan kompetensi yang bisa diamati dan mudah dikembangkan terdiri dari; pengetahuan (knowledge) dan keterampilan (skill). Sedangkan soft competency merupakan kompetensi yang sulit diamati dan sulit dikembangkan namun bisa dipelajari, yang terdiri dari; motif (motive), karakter (trait) dan konsep diri (self concept).

Kinerja pegawai (Y) mempengaruhi seberapa banyak mereka memberi kontribusi kepada organisasi. Perbaikan kinerja baik untuk individu maupun kelompok menjadi pusat perhatian dalam upaya meningkatkan kinerja. (Robert L. Mathis \& John H. Jackson, 2002:78)

Soedjono (2005) menyebutkan 6 (enam) kriteria yang dapat digunakan untuk mengukur kinerja pegawai secara individu yakni :

1. Kualitas, yaitu hasil pekerjaan yang dilakukan mendekati sempurna atau memenuhi tujuan yang diharapkan dari pekerjaan tersebut.

2. Kuantitas, yaitu jumlah yang dihasilkan atau jumlah aktivitas yang dapat diselesaikan.
3. Ketepatan waktu, yaitu dapat menyelesaikan pada waktu yang telah ditetapkan serta memaksimalkan waktu yang tersedia untuk aktivitas yang lain.

4. Efektivitas, yaitu pemanfaatan secara maksimal sumber daya yang ada pada organisasi untuk meningkatkan keuntungan dan mengurangi kerugian.

5. Kemandirian, yaitu dapat melaksanakan kerja tanpa bantuan guna menghindari hasil yang merugikan.

6. Komitmen kerja, yaitu komitmen kerja antara pegawai dengan organisasinya dan tanggung jawab pegawai terhadap organisasinya.

Berdasarkan kerangka pemikiran pada Gambar 1, rumusan hipotesis penelitian sebagai berikut:

H1 : Terdapat pengaruh yang signifikan motivasi terhadap kinerja pegawai pada bagian Humas dan Protokol di Sekretariat Daerah Kabupaten Paser.

H2 : Terdapat pengaruh yang signifikan kompetensi terhadap kinerja pegawai pada bagian Humas dan Protokol di Sekretariat Daerah Kabupaten Paser.

H3 :Motivasi kerja dan kompetensi secara bersama-sama berpengaruh signifikan terhadap kinerja pegawai pada bagian Humas dan Protokol di Sekretariat Daerah Kabupaten Paser. 


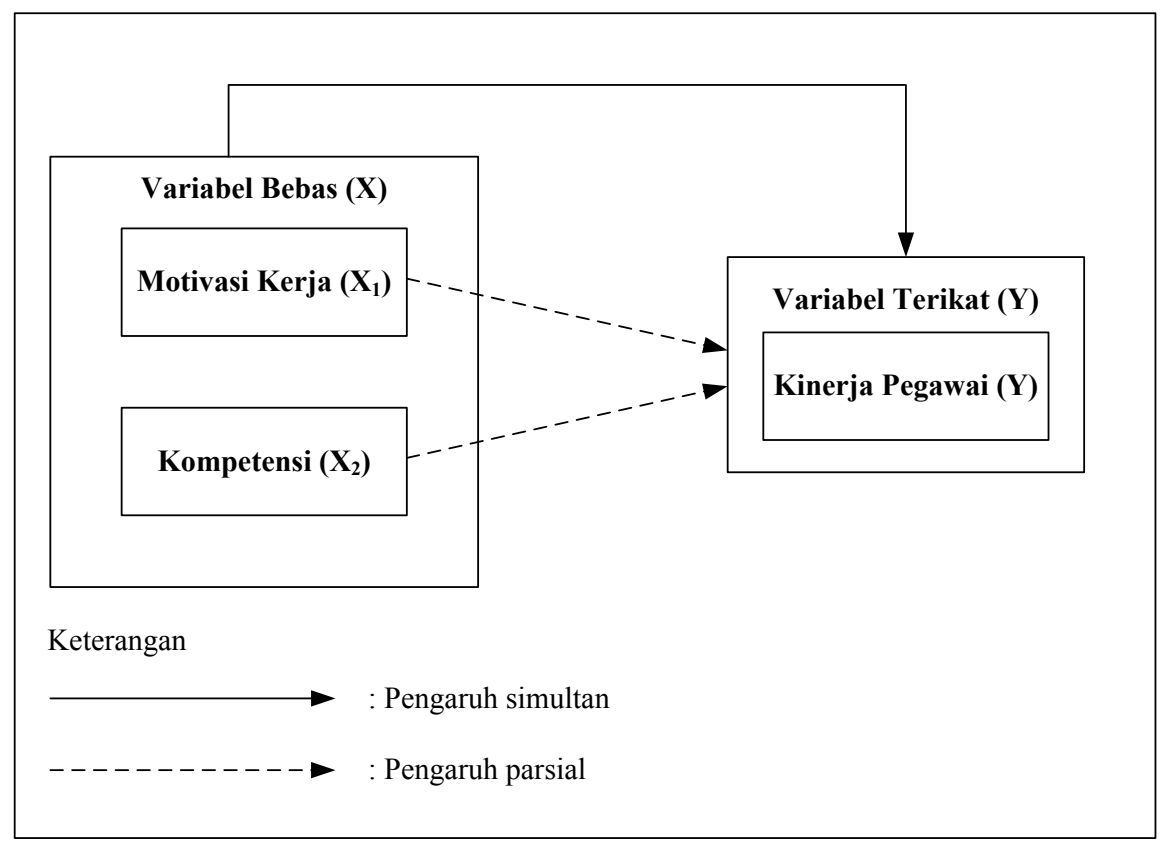

Gambar 1. Model Kerangka Berpikir

\section{METODE PENELITIAN}

\section{Jenis Penelitian}

\section{Lokasi dan Waktu Penelitian}

Penelitian ini dilaksanakan pada Bagian Humas dan Protokol Sekretariat Daerah Kabupaten Paser dengan waktu pelaksanaan bulan Maret 2016 hingga bulan Juni 2016. Data yang diperlukan pada penelitian ini yaitu motivasi, kompetensi, dan kinerja pegawai pada Bagian Humas dan Protokol di Sekretariat Daerah Kabupaten Paser. Variabel yang digunakan dalam penelitian ini yaitu variabel bebas ( motivasi sebagai X1 dan kompetensi sebagai X2) dan variabel terikat (kinerja pegawai sebagai Y)

\section{Populasi dan Sampel}

Populasi pada penelitian ini adalah seluruh Pegawai Negeri Sipil (PNS) pada Bagian Humas dan Protokol di Sekretariat Daerah Kabupaten Paser, yaitu sebanyak 32 orang. Jumlah sampel dalam penelitian ini berdasarkan prosedur pengambilan sampel dari jumlah populasi 32 orang, maka akan diambil seluruhnya yaitu 32 orang pegawai
Pada Bagian Humas dan Protokol di Sekretariat Daerah Kabupaten Paser. Sedangkan teknik sampel yang digunakan dalam penelitian ini adalah sampling jenuh.

\section{Teknik Pengumpulan data}

Sumber data yang digunakan pada penelitian ini terdiri dari data primer dan data sekunder. Data primer dalam penelitian ini adalah tanggapan responden terhadap kuesioner variabel motivasi dan kompetensi terhadap kinerja pegawai pada bagian Humas dan Protokol di Sekretariat Daerah Kabupaten Paser. Data sekunder dalam penelitian ini adalah karyawan, lokasi dan struktur organisasi serta tugas-tugas pegawai pada bagian Humas dan Protokol Sekretariat Daerah Kabupaten Paser.

Instrumen dalam penelitian ini adalah kuesioner, tabulasi dimana setiap item soal disediakan 5 jawaban dengan skor masingmasing adalah jawaban SS (Sangat Setuju) diberi skor 5, jawaban S (Setuju) diberi skor 4, jawaban N (Netral) diberi skor 3, jawaban TS (Tidak Setuju) diberi skor 2, dan jawaban 
STS (Sangat Tidak Setuju) diberi skor 1. Dalam penelitian ini, teknik pengumpulan data yang digunakan meliputi observasi, wawancara dan kuesioner.

\section{Analisis data}

Metode analisis data yang digunakan yaitu uji validitas, uji reliabilitas, uji asumsi klasik dan analisis regresi linier berganda. Uji validitas bertujuan untuk mengukur apakah pertanyaan dalam kuesioner yang telah dibuat dapat mengukur yang hendak diukur. Uji reliabilitas digunakan untuk mengetahui konsistensi dan stabilitas suatu skor dari kuesioner. Uji asumsi klasik digunakan sebelum melakukan analisis regresi linier berganda agar hasil analisis dapat dipercaya. Uji asumsi klasik terdiri dari uji normalitas, heteroskedastisitas, multikolinieritas dan autokorelasi. Sedangkan pada analisis regresi linier berganda dapat digunakan untuk mengetahui pengaruh motivasi dan kompetensi terhadap kinerja pegawai secara simultan dan parsial.

\section{HASIL DAN PEMBAHASAN}

\section{Hasil}

Koefisien Korelasi dan Koefisien Determinasi

Nilai koefisien korelasi dan koefisien determinasi dapat dilihat pada Tabel 1 sebagai berikut:

Tabel 1 menunjukkan bahwa nilai koefisien korelasi $(\mathrm{R})$ sebesar 0,711 ; artinya korelasi antara variabel bebas (motivasi $X_{1}$ dan kompetensi $X_{2}$ ) secara bersama-sama dengan variabel terikat (kinerja $Y$ ) sebesar 0,711; korelasi tersebut dikategorikan kuat.

Selain koefisien korelasi, Tabel 1 menunjukkan pula nilai koefisien determinasi (adjusted $\mathrm{R}$ square) sebesar 0,472 ; artinya variasi motivasi $\left(X_{1}\right)$ dan kompetensi $\left(X_{2}\right)$ dapat menjelaskan kinerja $(Y)$ sebesar 47,2\% sedangkan sisanya dijelaskan oleh faktor lain yang tidak diketahui sebesar $(100-47,2) \%=$
$52,8 \%$. Hal ini menunjukkan bahwa adanya faktor lain yang dapat menjelaskan kinerja $(Y)$ selain motivasi $\left(X_{1}\right)$ dan kompetensi $\left(X_{2}\right)$.

\section{Uji Signifikansi secara Simultan} Hipotesis

$\mathrm{H}_{0}: \beta_{1}=\beta_{2}=0$ (Secara simultan variabel bebas $\quad X_{1}, X_{2}, \cdots, X_{k} \quad$ tidak berpengaruh signifikan terhadap variabel terikat $Y$ )

$\mathrm{H}_{\mathrm{a}}$ : minimal terdapat satu $\beta_{j} \neq 0$ dengan $j=1,2$ (minimal terdapat satu variabel bebas yang berpengaruh signifikan terhadap variabel terikat $Y$ )

Statistik uji: Statistik uji yang digunakan yaitu uji $\mathrm{F}$ dengan perhitungan dapat dilihat pada Tabel 2.

Daerah kritik: $\mathrm{H}_{0}$ ditolak jika $F_{\text {hitung }}>F_{\text {tabel }} \quad$ dengan $F_{\text {tabel }}=\alpha ; k-1, n-k=4,17$ atau p-value $<\alpha$ Keputusan: Karena $F_{\text {hitung }}>F_{\text {tabel }}(14,834>$ $4,17)$ atau $\mathrm{p}$-value $<\alpha(0,000<0,05)$ maka $\mathrm{H}_{0}$ ditolak.

Kesimpulan: Minimal terdapat satu $\beta_{j} \neq 0$ dengan $j=1,2$ (minimal terdapat satu variabel bebas yang berpengaruh signifikan terhadap variabel terikat $Y$ ).

\section{Uji Signifikansi secara Parsial} Hipotesis

$\mathrm{H}_{0(\mathrm{X})}: \quad \beta_{1}=0 \quad$ (Motivasi $\quad\left(X_{1}\right)$ tidak berpengaruh signifikan terhadap kinerja (Y))

$\mathrm{H}_{\mathrm{a}(\mathrm{X})}: \beta_{1} \neq 0$ (Motivasi $\left(X_{1}\right)$ berpengaruh signifikan terhadap kinerja $(Y))$
$\mathrm{H}_{0(x 2)}: \beta_{2}=0 \quad$ (Kompetensi $\quad\left(X_{2}\right)$ tidak berpengaruh signifikan terhadap kinerja (Y))

$\mathrm{H}_{\mathrm{a}\left(\mathrm{x}_{2}\right)}: \beta_{2} \neq 0$ (Kompetensi $\left(X_{2}\right)$ berpengaruh signifikan terhadap kinerja $(\mathrm{Y}))$

Statistik uji: Uji $\mathrm{t}$ dengan hasil yang diperoleh sebagai berikut: 
Daerah kritik: $\mathrm{H}_{0}$ ditolak jika $\left|t_{\text {hitung }}\right|>t_{\text {tabel }}$ dengan $\quad t_{\text {tabel }}=\frac{\alpha}{2} ; n-k=0,05 / 2 ; 32-3$ $=0,025 ; 29=1,699$ atau $p$-value $<\alpha$

Keputusan: Karena $\left|t_{\text {hitung }(X 1)}\right|>t_{\text {tabel }}(5,440>$ $1,699)$ atau $\mathrm{p}$-value $<\alpha(0,000<0,05) \mathrm{H}_{0 \times 22}$ ditolak dan $\left|t_{\text {hitung }(X 2)}\right|<t_{\text {tabel }}(0,328<1,699)$ atau $\mathrm{p}$-value $>\alpha(0,745>0,05) \mathrm{H}_{0 \times(2)}$ gagal ditolak

Kesimpulan: $\quad \beta_{1} \neq 0 \quad$ (Motivasi $\quad\left(X_{1}\right)$ berpengaruh signifikan terhadap kinerja $(\mathrm{Y})$ ) dan $\quad \beta_{2}=0 \quad$ (Kompetensi $\left(X_{2}\right) \quad$ tidak berpengaruh signifikan terhadap kinerja $(Y)$ ).

Persamaan Regresi

Berdasarkan Tabel 3, persamaan regresi dapat ditulis sebagai berikut:

\section{$Y=0,379+0,8895 X_{1}-0,01 X_{2}$}

$b_{0}=0,379$; berarti tanpa adanya motivasi

$\left(X_{1}\right)$ dan kompetensi $\left(X_{2}\right)$ maka kinerja pegawai $(Y)$ sebesar 0,379 satuan.

$b_{1}=0,895 ;$ berarti setiap peningkatan

motivasi $\left(X_{1}\right)$ pegawai sebesar satu satuan maka kinerja pegawai akan meningkat sebesar 0,895 satuan.

$b_{2}=-0,041$;berarti setiap peningkatan

kompetensi $\left(X_{2}\right)$ pegawai sebesar satu satuan maka kinerja pegawai akan menurun sebesar 0,041 satuan.

Paradigma Pengaruh Motivasi Kerja terhadap kinerja karyawan dapat dilihat dari tabel... diketahui bahwa elastisitas Motivasi Kerja terhadap Kinerja Karyawan adalah sebesar $+0,895$ atau in elastis (kurang dari 1), berdasarkan elastisitas tersebut diketahui bahwa setiap adanya peningkatan motivasi kerja sebesar 1\%, maka akan mengakibatkan peningkatan kinerja karyawan sebesar 0,895\%. Dengan memperhatikan besarnya koefisien korelasi $(\mathrm{r}$ ) sebesar $+0,928$, maka dapat dinyatakan bahwa hubungan antara motivasi kerja adalah sangat kuat positif, artinya semakin meningkat motivasi kerja, maka akan semakin meningkatkan kinerja karyawan.

Paradigma Pengaruh lingkungan kerja terhadap kinerja karyawan dapat dilihat dari tabel 2 diketahui bahwa elastisitas Lingkungan Kerja terhadap Kinerja Karyawan adalah sebesar $+0,807$ atau in elastis (kurang dari 1), berdasarkan elastisitas tersebut diketahui bahwa setiap adanya peningkatan perbaikan lingkungan kerja sebesar 1\%, maka akan mengakibatkan peningkatan kinerja karyawan sebesar $0,807 \%$. Dengan memperhatikan besarnya koefisien korelasi $(r)$ sebesar $+0,953$, maka dapat dinyatakan bahwa hubungan antara lingkungan kerja adalah sangat kuat positif, artinya semakin meningkat perbaikan lingkungan kerja, maka akan semakin meningkatkan kinerja karyawan.

Dari tabel 2 variabel motivasi kerja dan lingkungan kerja jika secara bersama-sama dapat mempengaruhi kinerja karyawan. Dari data-data di atas secara simultan Motivasi Kerja dan Lingkungan Kerja diketahui bahwa besarnya koefisien korelasi ( $\mathrm{R}$ ) sebesar + 0,962, maka dapat dinyatakan bahwa hubungan antara motivasi kerja dan lingkungan kerja secara simultan adalah sangat kuat positif, artinya semakin meningkat motivasi kerja dan lingkungan kerja secara simultan, maka akan semakin meningkatkan kinerja karyawan.

Berdasarkan temuan di atas, bahwa thitung untuk parameter $\beta 1$ sebesar 3,629*, dan thitung untuk parameter $\beta 2$ sebesar 7,047**. Kaidah keputusan dinyatakan bahwa jika $t_{\text {hiums }}>t_{\text {wecc }}$, artinya pengaruhnya signifikan, dan sebaliknya jika thitung < ttabel, artinya pengaruhnya tidak signifikan. Berdasarkan data di atas, diketahui bahwa ttabel sebesar 1,671, sehingga secara parsial 
dapat dinyatakan bahwa motivasi kerja dan lingkungan kerja, masing-masing berpengaruh secara signifikan terhadap kinerja karyawan.

Tabel 1. Nilai Koefisien Korelasi dan Koefisien Determinasi

\begin{tabular}{|c|c|c|}
\hline Model & $\mathrm{R}$ & Adjusted R Square \\
\hline 1 & 0,711 & 0,472 \\
\hline
\end{tabular}

Sumber: Data diolah (2017)

Tabel 2. Uji Simultan

\begin{tabular}{|l|c|c|c|c|c|}
\hline $\begin{array}{c}\text { Source of } \\
\text { variation }\end{array}$ & Sum Square & $\begin{array}{c}\text { Degree } \\
\text { of } \\
\text { freedom }\end{array}$ & $\begin{array}{c}\text { Mean } \\
\text { Square }\end{array}$ & F hitung & Sig. \\
\cline { 1 - 4 } Regression & 3,102 & 2 & 1,551 & \multirow{2}{*}{14,834} & 0,000 \\
\hline Error & 3,032 & 29 & 0,105 & & \\
\hline Total & 6,134 & 31 & & & \\
\hline
\end{tabular}

Sumber: Data diolah (2017)

Tabel 3. Uji Signifikansi secara Parsial

\begin{tabular}{|c|c|c|c|}
\hline Variabel & Koefisien & thitung & p-value \\
\hline Konstanta & 0,379 & 0,451 & 0,655 \\
\hline Motivasi (X1) & 0,895 & 5,440 & 0,000 \\
\hline Kompetensi (X2) & $-0,041$ & $-0,328$ & 0,745 \\
\hline
\end{tabular}

Sumber: Data diolah (2017)

\section{Pembahasan}

Berdasarkan hasil analisis regresi linier berganda, pada pengujian signifikansi secara simultan dapat diketahui bahwa minimal terdapat satu variabel bebas; yaitu motivasi (X1) dan kompetensi (X2) yang berpengaruh signifikan terhadap kinerja pegawai (Y). Setelah dilakukan uji lanjut, yaitu pengujian signifikansi secara parsial menunjukkan bahwa hanya motivasi (X1) saja yang berpengaruh signifikan terhadap kinerja pegawai (Y).

Motivasi (X1) memiliki pengaruh terhadap kinerja pegawai karena motivasi berperan mendorong keinginan seseorang untuk melakukan suatu pekerjaan guna mencapai tujuan. Motivasi (X1) berpengaruh positif terhadap kinerja karyawan. Hal ini berarti jika motivasi ditingkatkan maka kinerja juga meningkat pula. Sesuai dengan teori McClelland sebagai grand theory untuk menjelaskan konsep teori secara umum tentang motivasi kerja, kebutuhan utama yang relevan di tempat kerja, yaitu:

Need for Achievement (nAch), kebutuhan untuk berprestasi, yang merupakan refleksi dari dorongan akan tanggung jawab untuk pemecahan masalah.

Need for Affiliation (nAff), kebutuhan untuk berhubungan sosial, yang merupakan dorongan untuk berinteraksi dengan orang lain atau berada bersama orang lain, tidak mau melakukan sesuatu yang merugikan orang lain. 
Need for Power (nPow), kebutuhan untuk berkuasa, yang merupakan refleksi dari dorongan untuk mencapai otoritas/ kekuasaan, serta untuk memiliki pengaruh terhadap orang lain.

Kompetensi (X2) tidak berpengaruh signifikan tehadap kinerja pegawai (Y). Hal ini disebabkan karena salah satu unsur tidak seimbang, pengalaman kerja, keterampilan serta karakter pegawai, maka tidak aneh jika kompetensi tidak berpengaruh signifikan terhadap kinerja pegawai (Y), artinya jika kompetensi (X2) ditingkatkan maka kinerja pegawai (Y) akan menurun.

Koefisien korelasi (R) sebesar 0,711; artinya korelasi antara variabel bebas (motivasi X1 dan kompetensi X2) secara bersama-sama dengan variabel terikat (kinerja Y) sebesar 0,711; korelasi tersebut dikategorikan kuat. Walaupun korelasi secara bersama-sama kuat, pada nilai koefisien determinasi (adjusted $\mathrm{R}$ square) sebesar 0,472 ; artinya variasi motivasi (X1) dan kompetensi (X2) dapat menjelaskan kinerja pegawai (Y) sebesar 47,2\% sedangkan sisanya dijelaskan oleh faktor lain yang tidak diketahui sebesar $(100-47,2) \%=52,8 \%$. Hal ini menunjukkan bahwa adanya faktor lain yang cukup besar yang dapat menjelaskan kinerja (Y) selain motivasi (X1) dan kompetensi (X2).

\section{KESIMPULAN DAN SARAN}

\section{Kesimpulan}

Berdasarkan pembahasan yang telah dilakukan, dapat disimpulkan bahwa secara parsial, motivasi berpengaruh signifikan terhadap kinerja pegawai Bagian Humas dan Protokol di Sekretariat Daerah Kabupaten Paser. Hal ini disebabkan karena motivasi berperan mendorong keinginan seseorang untuk melakukan suatu pekerjaan guna mencapai tujuan, sehingga semakin tinggi motivasi pegawai maka kinerja pegawai akan semakin baik. Selain itu, kompetensi tidak berpengaruh signifikan terhadap kinerja pegawai Bagian Humas dan Protokol di Sekretariat Daerah Kabupaten Paser. Hal ini disebabkan karena salah satu unsur tidak seimbang, pengalaman kerja, keterampilan serta karakter pegawai, maka tidak aneh jika kompetensi tidak berpengaruh signifikan terhadap kinerja pegawai, artinya jika kompetensi (X2) ditingkatkan maka kinerja pegawai akan menurun.

Secara simultan, minimal terdapat satu variabel antara motivasi dan kompetensi yang berpengaruh signifikan terhadap kinerja pegawai Bagian Humas dan Protokol di Sekretariat Daerah Kabupaten Paser. Setelah dilanjutkan pada pengujian signifikansi secara parsial, ternyata hanya motivasi yang berpengaruh signifikan terhadap kinerja pegawai Bagian Humas dan Protokol di Sekretariat Daerah Kabupaten Paser. Hal ini disebabkan karena motivasi sangat berpengaruh dominan terhadap kinerja pegawai Bagian Humas dan Protokol di Sekretariat Daerah Kabupaten Paser.

\section{Saran}

Berdasarkan pembahasan dan kesimpulan yang telah dilakukan, maka pada Pembina atau Pimpinan pada Pada Bagian Humas dan Protokol di Sekretariat Daerah Kabupaten Paser. Adanya kesediaan pimpinan untuk selalu mendiskusikan dan mendelegasikan sebagian wewenangnya kepada bawahanya pada indikator Kompetensi Kinerja Pegawai. Selain itu, pencapaian tujuan yang telah ditetapkan melalui kinerja pegawai, dengan terus mengembangkan komitmen kerja pegawai, keterampilan pegawai dan kebutuhan akan afiliasi Pada Bagian Humas dan Protokol di Sekretariat Daerah Kabupaten Paser.

Bagi para peneliti selanjutnya yang akan melakukan penelitian sejenis diharapkan mengambil sampel berdasarkan unit analisis para pegawai, dan selanjutnya dalam tahapan pengumpulan data disamping menggunakan cara kuesioner, juga dapat dilaksanakan wawancara guna dapat lebih mempertajam dalam mengkualitifikasikan hasil analisis dan pembahasan penelitian disamping dengan cara kuantitatif (analisis statistik).

Beberapa keterbatasan yang dimiliki dalam penelitian ini diantaranya adalah belum mampu menampilkan semua indikator yang mungkin terkait dalam variabel 
motivasi kerja dan variabel lingkungan kerja dengan pembentukan dan pencapaian kinerja karyawan Rektorat Universitas Islam Kalimantan (Uniska) Muhammad Arsyad Al Banjary Banjarmasin. Terbatasnya studi penelitian terdahulu yang diketahui penulis berkenaan dengan variabel motivasi kerja dan lingkungan kerja, sehingga hal tersebut menjadi kendala dalam membahas hasil penelitian yang berkaitan dengan kinerja karyawan. Disadari pula bahwa penelitian ini belum memasukkan faktor kondisi sosial ekonomi karyawan di lingkungan kerja Rektorat Universitas Islam Kalimantan (Uniska) Muhammad Arsyad Al Banjary Banjarmasin itu berada, yang menyebabkan belum tajamnya analisis kinerja karyawan terutama variabel atau faktor motivasi kerja, di samping variabel lingkungan kerja.

\section{DAFTAR PUSTAKA}

Abdussamad, J., \& Si, M. (2017). Analisis Budaya Organisasi dalam Meningkatkan Kinerja pada Dinas Pendidikan Pemuda dan Olahraga Provinsi Gorontalo.

Buhler, Patricia. (2004). Alpa Teach Yourself. Management Skills dalam 24 Jam. Terj. Jakarta: Prenada Media.

Hasibuan, M. (2003). Manajemen Sumber Daya Manusia. Jakarta : PT.Bumi.

Maulida, N. (2018). Pengaruh Komunikasi Dan Motivasi Terhadap Kinerja Karyawan Pt Bess Finance Banjarmasin. At-Tadbir: jurnal ilmiah manajemen, 2(1).

Lamsah, L. (2018). Pengaruh Motivasi Dan Kepuasan Kerja Terhadap Kinerja Ukm. At-Tadbir: jurnal ilmiah manajemen, 2(2).

Nisa, K., Serudji, J., \& Sulastri, D. (2019). Analisis Faktor yang Berhubungan dengan Kinerja Bidan dalam Memberikan Pelayanan Antenatal Berkualitas Diwilayah Kerja Puskesmas Kota Bukittinggi Tahun 2018. Jurnal Ilmiah Universitas Batanghari Jambi, 19(1), 53-60.
Pramudyo, Anung, 2010, Analisis FaktorFaktor yang Mempengaruhi Kinerja Dosen Negeri Dipekerjakan pada Kopertis Wilayah V Yogyakarta. Vol.1 No.1.

Robbins, Stephen P. (2006). Perilaku Organisasi (alih bahasa Drs. Benjamin Molan), Edisi Bahasa Indonesia, Klaten: PT INT AN SEJATI.

Robbins, S., dan Timothy A. J. (2008). "Perilaku Organisasi, Organizational Behaviour”, Buku Terjemahan, Jakarta : Gramedia.

Rivai, Veithzal dan Sagala, Ella Jauvani. 2009. Manajemen Sumber Daya Manusia untuk Perusahaan. Edisi Kedua, Raja Grafindo Persada, Jakarta.

Spencer, LM. (1992). Competency Assessment Method : History and State of the Art. Boston: Hay / McBer Research Press.

Spencer, LM. (1993). Competencyat Work : Model for Superior Performance. Devie Fitri Octaviani, FKM UI, 2010. USA: John Wiley \& Son

Spencer,M.Lyle and Spencer,M.Signe, 1993, Competence at Work:Models for Superrior Performance, John Wily \& Son,Inc,New York,USA

Soedjono. 2005. Pengaruh Budaya Organisasi terhadap Kinerja Organisasi dan kepuasan Kerja Karyawan pada Terminal Penumpang Umum di Surabaya. Jurnal Manajemen dan kwirausahaan Vol. 7 No. 1. STIESIA Surabaya.

Suherman, E., \& Savitri, C. (2018). Analisis Peran Self efficacy dan Motivasi Kerja Terhadap Kinerja Marketing Dealer Wijaya Toyota Subang. Buana Ilmu, $3(1)$.

Sugiyono. (1999). Metode Penelitian Bisnis. Jakarta: Alfabeta

Sugiyono (2016). Metode Penelitian Bisnis. Jakarta: Alfabeta.

Sugiyono. 2015. Statistika untuk Penelitian. Bandung : Alfabeta.

Usman, Husaini dan Purnomo Setiadi Akbar. 2006. Pengantar Statistika. 